BBA 76019

PREPARATION OF PURIFIED MYELIN FROM OX INTRADURAL SPINAL ROOTS BY RATE-ISOPYCNIC ZONAL CENTRIFUGATION

\title{
Y. LONDON
}

Laboratory of Biochemistry, State University of Utrecht, Vondellaan 26, Utrecht (The Netherlands) (Received April I Ith, 1972)

\section{SUMMARY}

I. Ox peripheral nerve myelin membranes were isolated by rate-isopycnic zonal centrifugation. A method is described for the Beckman size I4 zonal rotor. The isolated membranes had the same isopycnic banding density as $15.2 \%$ sucrose $(w / w)$. On the basis of studies with twelve marker enzymes and electron microscopy, at least $99 \%$ of the fraction consisted of myelin membranes. The electron micrographs showed the typical myelin lamellar rings and vesicles derived by peeling off from these lamellae.

2. The enzyme, $2^{\prime}, 3^{\prime}$-cyclic nucleotide- $3^{\prime}$-phosphohydrolase, reported to be closely associated with central nervous system myelin, was shown not to be associated with the peripheral nerve myelin.

3. A membrane fraction which had the same isopycnic banding density as I $7.6 \%$ sucrose $(\mathrm{w} / \mathrm{w})$ was shown to have high specific activity of $5^{\prime}$-nucleotidase and $2^{\prime}, 3^{\prime}$-cyclic nucleotide- $3^{\prime}$-phosphohydrolase. A similar fraction was isolated from ox spinal cord. This fraction of the spinal cord membranes banding at $17.6 \%(\mathrm{w} / \mathrm{w})$ contained no basic protein.

4. The disc electrophoresis pattern of the peripheral nerve myelin proteins was different from that of the spinal cord myelin.

\section{INTRODUCTION}

The myelin sheath has been the subject of extensive investigation. In the past two years considerable interest has been focused on the study of isolated myelin membranes from brain ${ }^{1-4}$, spinal $\operatorname{cord}^{5}$ and peripheral nerve ${ }^{6-8}$. The earlier published procedures of preparing myelin were long and involved repeated centrifugations, usually in a single solvent or in discontinuous gradients. Since in these methods the sample was collected as a pellet or as a cohesive condensed layer at the interface, contamination with other material could not be avoided ${ }^{9}$. Osmotic shock of myelin was utilized to free the myelin from axoplasmic contamination; unfortunately, shock procedures present the possibility of losing enzymes bound to the membrane by bonds which are readily ruptured due to the reduction in ionic strength ${ }^{7}, 10$.

The recovery of pure myelin membranes prepared by these methods is usually low and, in addition, the methods are time consuming. With rate-isopycnic zonal 
centrifugation as reported in this paper, a myelin preparation from peripheral nerve is recovered which appears to be of high purity and high yield, in a minimal time after the death of the animal. Also a "myelin-like" fraction reported by Agrawal et al. ${ }^{25}$ is partially purified.

\section{MATERIALS AND METHODS}

\section{The isolation of myelin membranes by rate-isopycnic zonal centrifugation}

Myelin membranes were isolated from ox spinal root sheats and ox spinal cord, with the Beckman $\mathrm{Ti}_{4}$ rotor. The nerves were removed about Io min after the death of the animal and kept in ice. For each preparation $\mathrm{I}-4.5 \mathrm{~g}$ of nerves or $\mathrm{I} \mathrm{g}$ of spinal cord was homogenized with a Servall mixer run at top speed (I5500 rev./min) for $60 \mathrm{~s}$ in o.I $\mathrm{M}$ isotonic phosphate buffer $\mathrm{pH}$ 7.2, plus $0 . \mathrm{I}$ mM EDTA (22.2 $\mathrm{ml}$ of $\mathrm{r} .0$ $\mathrm{M} \mathrm{NaH}{ }_{2} \mathrm{PO}_{4} \cdot \mathrm{H}_{2} \mathrm{O}$ and $354 \mathrm{ml}$ of $0.25 \mathrm{M} \mathrm{NaHPO} \cdot 2 \mathrm{H}_{2} \mathrm{O}$, final volume I 1). The nerve to buffer ratio was I $g$ to $I 0 \mathrm{ml}(\mathrm{w} / \mathrm{v})$. The homogenate was filtered through eight layers of cheese cloth and the filtrate was brought to a final volume of $50 \mathrm{ml}$ with the isotonic buffer and used directly for zonal centrifugation.

With a Beckman I4I High Capacity gradient pump, a 300-ml concave density gradient ranging from 5 to $\mathrm{I} 7 \%$ sucrose $(\mathrm{w} / \mathrm{w})$ was delivered into a $\mathrm{Ti}$ I 4 zonal rotor rotating at $3000 \mathrm{rev} . \mathrm{min}$ in a Beckman L $2-65 \mathrm{~K}$ centrifuge. The gradient was introduced into the rotor, followed by $200 \mathrm{ml}$ of $25 \%$ sucrose $(\mathrm{w} / \mathrm{w})$ and then $\mathrm{I} 50 \mathrm{ml}$ of $35 \%$ sucrose $(w / w)$ (Table I). The overlay and cushion solutions used were o.I $\mathrm{M}$ isotonic phosphate buffer, $\mathrm{pH} 7.2$, containing o.I mM EDTA and $35 \%$ sucrose $(\mathrm{w} / \mathrm{w})$, respectively. Following the injection of $50 \mathrm{ml}$ of sample material and $50 \mathrm{ml}$ of overlay into the rotor core, the rotor was accelerated to $5000 \mathrm{rev} . \mathrm{min}$ to achieve a rate separation. After $20 \mathrm{~min}$, the rotor speed was reduced to $3000 \mathrm{rev} / \mathrm{min}$ and $\mathrm{I} 5 \mathrm{ml}$ of overlay were injected through the rotor core in order to displace trapped air. Eight to ten 20-ml fractions were removed from the rotor by pumping in $35 \%$ sucrose $(w / w)$. The outflow transmittance was continuously monitored at $254 \mathrm{~nm}$ with a LKB uvicord II recorder. The rotor speed was increased to $40000 \mathrm{rev}$./min for I h to achieve isopycnic banding. After the rotor was decelerated to $3000 \mathrm{rev} . / \mathrm{min}$ the remaining gradient was unloaded.

Refractive indices were measured at $20^{\circ} \mathrm{C}$ in a Bausch and Lomb Abbe- 32 refractometer. Turbidity of the fractions was measured at $400 \mathrm{~nm}$ with a Unicam SP

\section{TABLE I}

RATE-ISOPYCNIC CENTRIFUGATION SYSTEM FOR CENTRAL AND PERIPHERAL MYELIN PREPARATION ROTOR Ti-14

Stage 1 : Rate separation at $5000 \mathrm{rev} . / \mathrm{min}$ for $20 \mathrm{~min}$; eluted: $180-200 \mathrm{ml}$ at $3000 \mathrm{rev} / \mathrm{min}$. Stage 2: Isopycnic banding at $40000 \mathrm{rev} / \mathrm{min}$ for $60 \mathrm{~min}$; eluted at $3000 \mathrm{rev} . / \mathrm{min}$.

$\begin{array}{ll}\text { Component Solution } & \begin{array}{l}\text { Volume } \\ (m l)\end{array}\end{array}$

Overlay

Sample

Gradient

First interface

Cushion o. I $\mathrm{M}$ isotonic phosphate buffer, $\mathrm{pH} 7.2,0.1 \mathrm{mM}$ EDTA

o.I $\mathrm{M}$ isotonic phosphate buffer, $\mathrm{pH} 7.2,0.1 \mathrm{mM}$ EDTA

$5 \%-\mathrm{x} 7 \%$ sucrose $(\mathrm{w} / \mathrm{w})$

$25 \%$ sucrose $(w / w)$

$35 \%$ sucrose $(w / w)$ 
500 spectrophotometer. The myelin-containing fractions and other fractions to be studied were diluted I: I $(\mathrm{v} / \mathrm{v})$ with cold distilled water and sedimented at ro5000 $\times$ $g$ for $60 \mathrm{~min}$ in the Beckman No. 30 rotor. Collected pellets were stored at $-20^{\circ} \mathrm{C}$. The recovery of myelin was approx. $\mathbf{I 2 . 5}-20 \mathrm{mg}$ protein per $\mathrm{g}$ wet tissue, and that of the fraction banded at $\mathbf{I} 7.6 \%$ sucrose $(\mathrm{w} / \mathrm{w})$ approx. $0.5^{-2} \mathrm{mg}$ protein per $\mathrm{g}$ wet tissue.

\section{Marker enzymes}

The following enzymes were used as markers and assayed as described in the references indicated: succinate: cytochrome $c$ reductase $^{11}$ (EC I.3.99.x); monoamine oxidase ${ }^{12}$ (EC $x .4 .3 .4$, substrate kynuramine); rotenone insensitive NADPH: cytochrome $c$ reductase $^{13}$ (EC I.6.2.3); acid deoxyribonuclease ${ }^{14}$ (EC 2.I.4.6); acid phosphatase ${ }^{15}$ (EC 3.I.3.2) substrate $\beta$-glycerophosphate; $5^{\prime}$-nucleotidase (EC 3.I.3.5, substrate 5'-AMP) ${ }^{16} ;\left(\mathrm{Na}^{+}, \mathrm{K}^{+}, \mathrm{Mg}^{2+}\right) \mathrm{ATPase}^{16}$ (EC 3.6.I.4); glucose-6-phosphatase ${ }^{17}$ (EC 3.I.3.9); L-leucyl- $\beta$-naphthylamidase (EC 3.4.I.I, leucine aminopeptidase) ${ }^{18}$; acetylcholinesterase (EC 3.I.I.7) ${ }^{19}$; and 2', $3^{\prime}$-cyclic nucleotide-3'-phosphohydrolase ${ }^{20}$. Spectrophotometric measurements were carried out in a Unicam SP 500 spectrophotometer and in a Hitachi-Perkin Elmer 365 double-wavelength spectrophotometer. Protein was measured according to the method of Lowry ${ }^{21}$, organic phosphorus according to that Böttcher et al. ${ }^{22}$, and inorganic phosphorus according to that Olafsen et al. ${ }^{20}$.

\section{Electron microscopy}

The membranes were fixed with $\mathrm{OsO}_{4}$, embedded in Araldite $5^{\mathrm{I} 2}$ and stained with uranylacetate followed by staining with lead citrate ${ }^{23}$. The specimens were examined in a Siemens Elmiskop I electron microscope.

\section{Disc electrophoresis}

Acrylamide electrophoresis was carried out as described by Takayama ${ }^{24}$ at $\mathrm{pH}$ 2.0. The gels were fixed with $7.5 \%$ acetic acid, stained with I\% solution of amido black in $7.5 \%$ acetic acid. Gels were destained electrically.

\section{Chemicals}

ATP, kynuramine $\cdot 2 \mathrm{HBr}$, glucose-6-phosphate and adenosine $2^{\prime}-3^{\prime}$-cyclic phosphate were purchased from Sigma (U.S.A.), AMP from Merck (Germany), cytochrome $c$ from Fluka (Switzerland), NADPH and NADH from Boehringer (Germany), rotenone from Aldrich (U.S.A.), DNA from Koch-Light (G.B.), Escherichia coli alkaline phosphate from Worthington (U.S.A.), L-leucyl- $\beta$-naphthylamide $\cdot \mathrm{HCl}$ and $\beta$-naphthylamine from Fluka. Al• other chemicals used were of analytical grade.

\section{RESULTS}

\section{Sedimentation properties of spinal root sheet myelin}

Typical sedimentation profiles of myelin are shown in Figs. I and 2. The average banding density for 40 runs was approx. $1.066 \mathrm{~g} / \mathrm{ml}, I_{5.2} \%$ sucrose $(\mathrm{w} / \mathrm{w})$. The membrane fraction with a banding density the same as that of $17.6 \%$ sucrose $(\mathrm{w} / \mathrm{w})$ was also present in the spinal cord (Fig. 3). By contrast, the myelin derived from the spinal cord was resolved into three peaks with banding densities equivalent to those of $11.0 \%, 14.0 \%$, and $16.0 \%$ sucrose (w/w) (Fig. 3 ). 
The peripheral nerve and the spinal cord myelin were found to have a phospholipid to protein ratio of $I .8(\mathrm{w} / \mathrm{w})$ while the fraction banding at $17.6 \%$ sucrose $(\mathrm{w} / \mathrm{w})$ had a ration of $0.9(\mathrm{w} / \mathrm{w})$. The recovery of myelin was approx. 12.5-20 $\mathrm{mg}$ protein per $\mathrm{g}$ wet tissue and that of the fraction banded at $\mathrm{r} 7.6 \%$ sucrose $(\mathrm{w} / \mathrm{w})$ approx. $0.5^{-2} \mathrm{mg}$ protein per $g$ wet tissue.

\section{Distribution of marker enzymes}

Table II shows the specific activities of enzymes present in the total homogenates of peripheral nerve, in the peripheral nerve myelin, and in the $17.6 \%$ sucrose

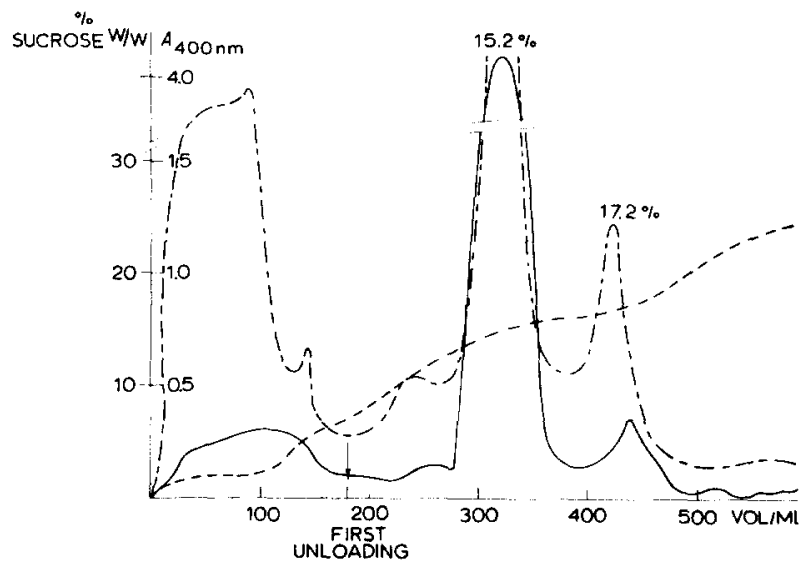

Fig. I. Rate-isopycnic zonal separation of myelin membranes and the "myelin-like" membrane fraction of ox intradural spinal roots, in the $\mathrm{Ti} \mathrm{I}_{4}$ rotor. The myelin banded at $15.2 \%$ sucrose $(w / w)$, and the "myelin-like" fraction at $17.6 \%$ sucrose $(w / w)$. The specific activity of $2^{\prime}, 3^{\prime},-c y c l i c$ nucleotide- $3^{\prime}$-phosphohydrolase and $5^{\prime}$-nucleotidase in the $17.6 \%$ fraction were 1580 and 162 $\mathrm{nmoles} / \mathrm{min}$ per $\mathrm{mg}$ protein, respectively, ——, $A_{400 \mathrm{~nm}} ;---, A_{254 \mathrm{~nm}} ;---\cdots, \%$ sucrose $(\mathrm{w} / \mathrm{w})$.

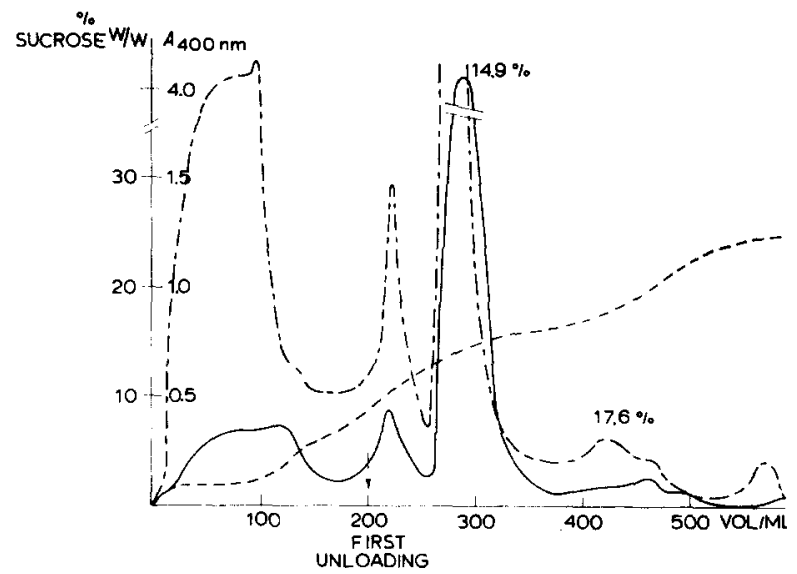

Fig. 2. Rate-isopycnic zonal separation of myelin membranes and the "myelin-like" membrane fraction of ox intradural spinal roots in the $\mathrm{Ti} \mathrm{I}_{4}$ rotor. The myelin banded at $\mathrm{I}_{4} .9 \%$ sucrose $(\mathrm{w} / \mathrm{w})$ and the "myelin-like" fraction at $17.6 \%$ sucrose. The specific activity of $2^{\prime}, 3^{\prime}$-cyclic nucleotide- $3^{\prime}$-phosphohydrolase and $5^{\prime}$-nucleotidase in the $17.6 \%$ sucrose fraction were $337^{\circ}$ and 235.4 nmoles/min per $\mathrm{mg}$ protein, respectively.,$- A_{400 \mathrm{~nm}} ;-\cdots, A_{254} \mathrm{~nm} ;-\cdots, \%$ sucrose $(w / w)$. 
$(\mathrm{w} / \mathrm{w})$ membrane fraction. The activities of mitochondrial, microsomal, lysosomal and plasma membrane marker enzymes are reduced to almost zero in the myelin fraction. In the peripheral nerve $2^{\prime}, 3^{\prime}$-cyclic nucleotide- $3^{\prime}$-phosphohydrolase was found not to be associated with the myelin fraction and a 5-9-fold increase in the specific activity of this enzyme was found in the $57.6 \%$ sucrose $(\mathrm{w} / \mathrm{w})$ membrane fraction, which was also enriched in $5^{\prime}$-nucleotidase activity. Spinal cord total homogenate (Table III) was found to have 4 -fold higher activity of $2^{\prime}, 3^{\prime}$-cyclic nucleotide$3^{\prime}$-phosphohydrolase than peripheral nerve total homogenate; the central nerve

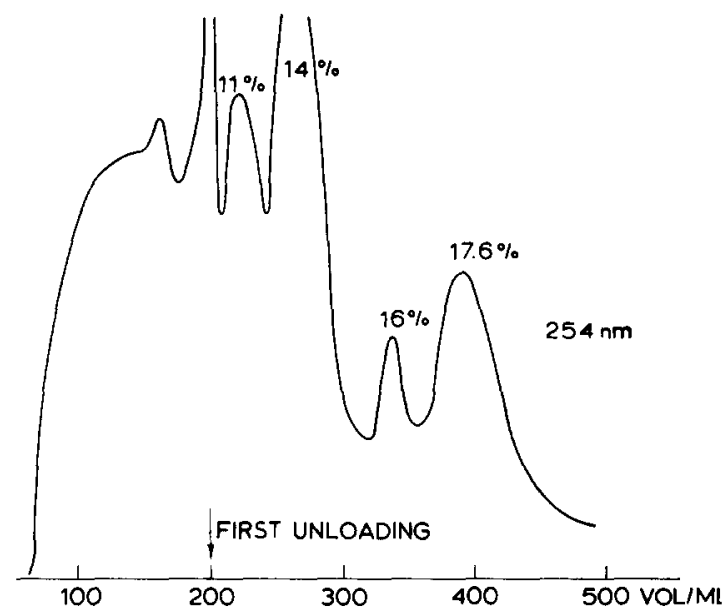

Fig. 3. Rate-isopycnic zonal separation of myelin membranes and the "myelin-like" membrane fraction of ox spinal cord, in the $\mathrm{Ti}$ I 4 rotor. The myelin banded at II \%, I4 $\%$ and $\mathrm{I}_{6} \%$ sucrose $(\mathrm{w} / \mathrm{w})$ and the "myelin-like" fraction at $\mathrm{I} 7.6 \%$ sucrose $(\mathrm{w} / \mathrm{w})$.

TABLE II

SPECIFIC ACTIVITIES * OF MARKER ENZYMES IN PERIPHERAL NERVE MYELIN FRACTIONS

\begin{tabular}{|c|c|c|c|}
\hline Marker enzyme & $\begin{array}{l}\text { Total } \\
\text { homogenate }\end{array}$ & Myelin & $\begin{array}{l}I 7.6 \% \text { sucrose } \\
(w / w) \text { fraction }\end{array}$ \\
\hline Glucose-6-phosphatase & 27.0 & o & not determined \\
\hline \multicolumn{4}{|l|}{ Rotenone-insensitive } \\
\hline NADPH : cytochrome $c$ reductase & 51.0 & 0.05 & not determined \\
\hline Acid DNAase & $5^{8.6}$ & 0 & not determined \\
\hline Acid phosphatase & 6.5 & o & not determined \\
\hline Succinate: cytochrome $c$ reductase & 273 & 3.6 & not determined \\
\hline $5^{\prime}$-Nucleotidase & 28.6 & o & $162^{\star \star}-235.4^{\star \star \star}$ \\
\hline$\left(\mathrm{Na}^{+}, \mathrm{K}^{+}, \mathrm{Mg}^{2+}\right)$-ATPase & 22.6 & 0 & o \\
\hline Acetylcholinesterase & - & o & \\
\hline Leucine aminopeptidase & 6.8 & 0 & not determined \\
\hline Monoamine oxidase & - & o & not determined \\
\hline $2^{\prime}, 3^{\prime}$-Cyclic nucleotide-3'-phosphohydrolase & $37^{0-500}$ & $200-420$ & $1580^{\star \star}-3370^{\star \star \star}$ \\
\hline
\end{tabular}

* The specific activities are expressed as nmoles substrate or product broken down or formed per min per mg protein.

$\star *$ Zonal profile as shown in Fig. I.

** Zonal profile as shown in Fig. 2. 
TABLE III

2', $3^{\prime}$-CYCLIC NUCLEOTIDE-3'-PHOSPHOHYDROLASE * AND 5'-NUCLEOTIDASE * * ACTIVITIES IN OX SPINAL CORD AND PERIPHERAL NERVE FRACTIONS

\begin{tabular}{|c|c|c|c|c|c|}
\hline & $\begin{array}{l}\text { Total } \\
\text { homogenate }\end{array}$ & Supernatant & Myelin & $\begin{array}{l}\text { Fraction I8 } \\
(16 \% \text { sucrose })\end{array}$ & $\begin{array}{l}\text { Fraction } I 7 \\
(6 \% \text { sucrose })\end{array}$ \\
\hline Peripheral nerve & I $8-20(28.6)$ & o.I 6 & $0.2-0.4(0)$ & & I. $5^{8-3 \cdot 37}($ I $62-235 \cdot 4)$ \\
\hline Spinal cord & $79 \quad(7 \cdot 3)$ & - & $6.65 \quad(0)$ & $6.37(0)$ & $(5+3)$ \\
\hline
\end{tabular}

*The activity of the $2^{\prime}, 3^{\prime}$-cyclic nucleotide- $3^{\prime}$-phosphohydrolase is expressed in $\mu$ moles substrate hydrolysed/min per $\mathrm{mg}$ protein, except for the total homogenate where the activity is in $\mu$ moles/min per g wet wt. protein.

$\star \star 5^{\prime}$-Nucleotidase activity is given in parentheses and is expressed in nmoles/min per $\mathrm{mg}$

myelin fractions had 20-fold higher activity of this enzyme than the peripheral nerve myelin fractions. The membrane fraction purified from the spinal cord with isopycnic banding at $17.6 \%$ sucrose $(\mathrm{w} / \mathrm{w})$ was enriched in $2^{\prime}, 3^{\prime}$-cyclic nucleotide- $3^{\prime}$-phosphohydrolase and had 7 -fold higher specific activity of $5^{\prime}$-nucleotidase as compared to the activity of the total homogenate of the spinal cord.

\section{Electron microscopy of isolated myelin}

Electron micrographs of the isolated peripheral nerve myelin showed no other recognizable cellular organelles. Most of the myelin was present entirely as lamellar rings and vesicles derived from layers detached from the myelin (Fig. 4 A and B). The split occurs between intraperiodic lines (Fig. 4C). The thinnest structure being one major dense line and two intraperiodic lines, no fragments of axoplasma were seen embedded within the myelin rings. The fraction banding isopycnically at $17.6 \%$ sucrose (w/w) (Fig. 5) showed myelin-like fragments and a membrane sheet which resembles the myelin-like fraction reported by Agrawal et al. ${ }^{25}$.

\section{Disc electrophoresis}

When the different subcellular fractions, the peripheral myelin fraction, the spinal cord myelin fraction, and the $17.6 \%$ fractions were solubilized in $2 \mathrm{M}$ urea in phenol-acetic acid-water $(2: I: I, w / v / v)$ and subjected to electrophoresis in $10 \%$ $(\mathrm{v} / \mathrm{v})$ acetic acid as described by Takayama ${ }^{24}$, a very simple electrophoretic pattern was observed. The peripheral nerve myelin (Fig. 6, tube 2) showed only three major proteins while the spinal cord myelin (Fig.6, tube 3) was characterized by the presence of the basic proteins, also present in the peripheral nerve myelin, and by the absence of the major protein which appears in peripheral nerve myelin. This demonstrates the difference between the protein composition of central and peripheral nervous system myelin (Fig. 6). The "myelin-like" fraction derived from the spinal cord banding isopycnically at $\mathrm{I} 7.6 \%$ sucrose (w/w) (Fig. 6, tube 4) showed, except for the absence of the basic protein, a higher content of high molecular weight proteins as compared to that of spinal cord myelin (Fig. 6, tube 3). The similar fraction derived from the peripheral nerve showed almost the same electrophoretic pattern as the myelin fraction, probably because of contamination with myelin fragments. 

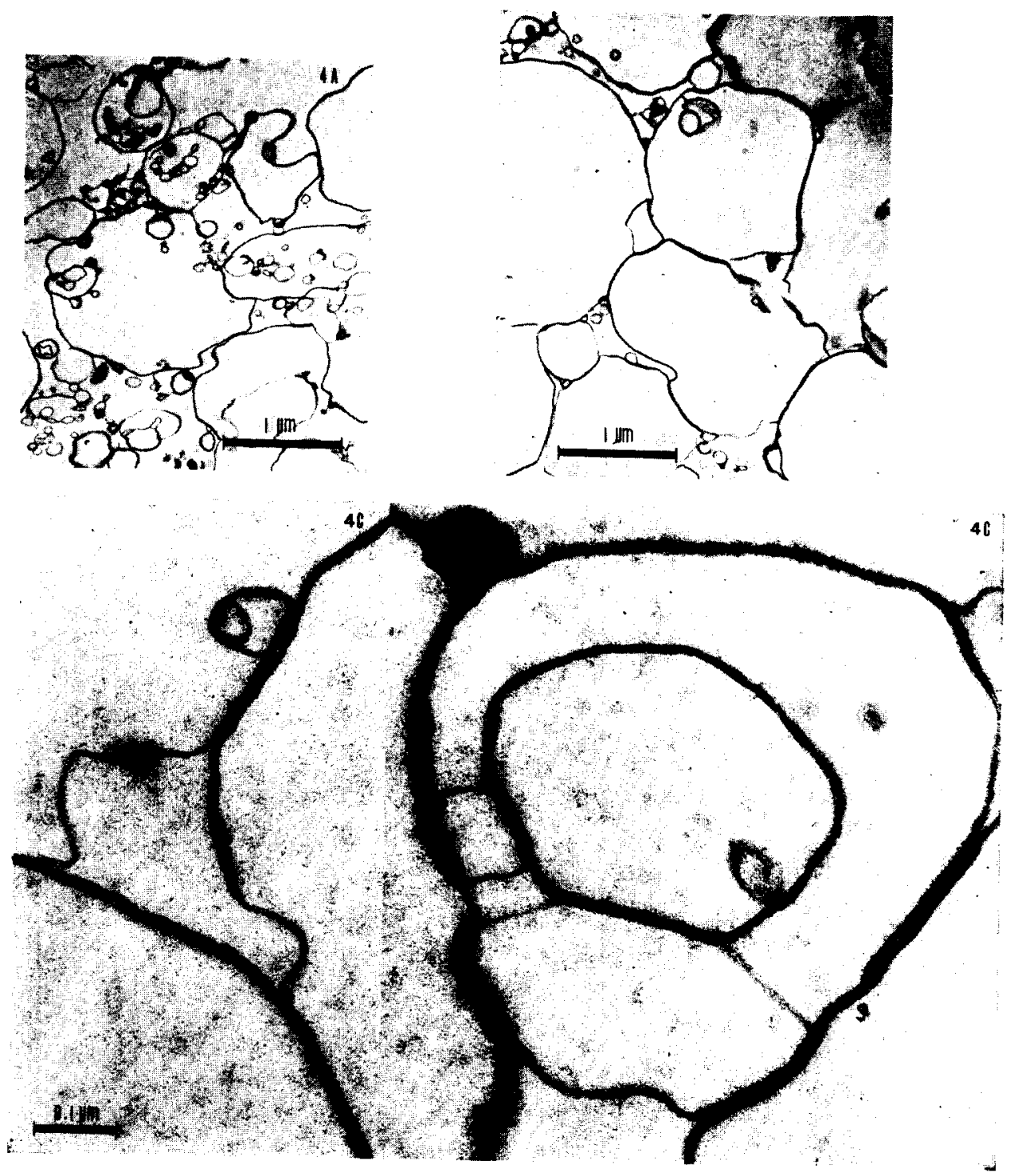

Fig. 4. Electron micrographs of thin sections of intradural spinal root myelin membranes. A. Low magnification survey micrography showing myelin membranes and the absence of mitochondria and trapped axoplasma. $B$ and $C$. High magnification micrographs of myelin membranes showing vesicles peeling off and splitting off at the intraperiodic line.

\section{DISCUSSION}

Only a few reports have appeared on the isolation of myelin membranes by zonal centrifugation ${ }^{26-28}$, and these only dealt with central nervous system myelin. The reports concerning purification of peripheral nerve myelin use the classical method of Autilio et al. ${ }^{1}$ and the recovery is low? 

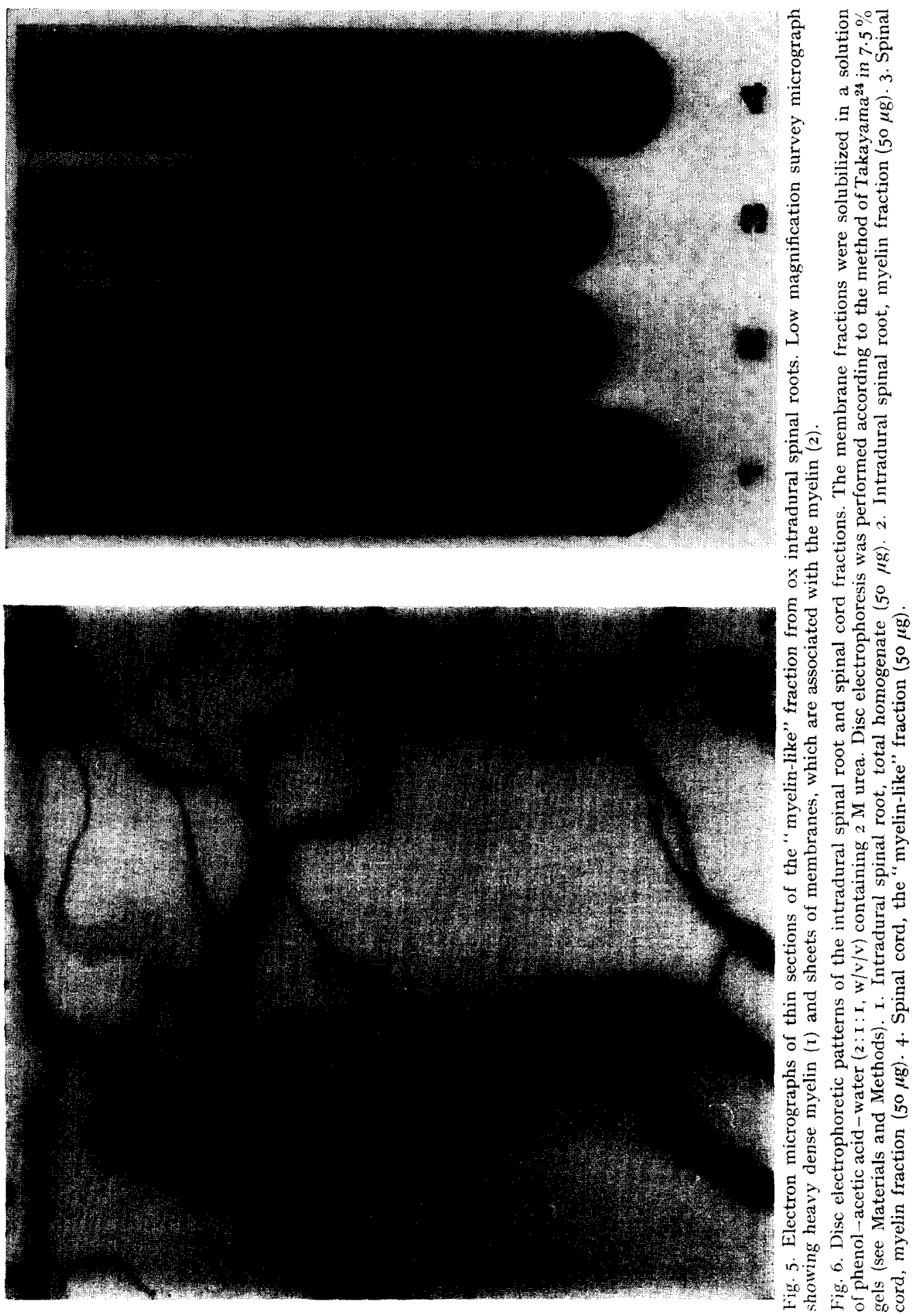

Biochim. Biophys. Acta, 282 (1972) 195-204 
higher than any other previously reported 7,8 and recovers between 20 and $25 \%$ of the total protein content of the nerve homogenate. The results of the marker enzymes tests, the phospholipid to protein ratio of I.8, and the electron microscopic appearence clearly indicate that there is no significant contamination of our myelin preparation with any other organelles or with axoplasma. The isolated peripheral nerve myelin showed a banding density equivalent to that of $55.2 \%$ sucrose $(w / w)$, far from that of other nervous tissue organelles.

Autilio et al. ${ }^{1}$ obtained their most dense and most concentrated fraction of myelin at $\mathrm{I} .094 \mathrm{~g} / \mathrm{ml}(23 \%$ sucrose, $\mathrm{w} / \mathrm{w})$. When myelin was prepared from spinal cord (central nervous system), the myelin formed three isopycnic bands at II \%, $14.0 \%$ and $16 \%$ sucrose $(\mathrm{w} / \mathrm{w})$, depending on the gradient steepness. Myelin did not form bands beyond these densities. When the purified myelin was banded isopycnically on a linear gradient between $5 \%$ and $35 \%$ sucrose $(w / w)$, no new myelin bands were seen. These results are in good agreement with the results of Day et al. ${ }^{28}$ who showed in their zonal centrifuge profiles of rat brain homogenates the same banding densities for myelin. The enzyme $2^{\prime}, 3^{\prime}$-cyclic nucleotide- $3^{\prime}$-phosphohydrolase was reported by Kurihara and Tsukada ${ }^{29}$ and others ${ }^{20,30,-33}$ to be exclusively located or strongly associated with the myelin sheath of the central nervous system. It was found that the total activity of the $2^{\prime}, 3^{\prime}$-cyclic nucleotide- $3^{\prime}$-phosphohydrolase in the peripheral nerve homogenate was only one-fourth of the total activity in the spinal cord homogenate. In contrast to the spinal cord myelin, the activity in the peripheral nerve myelin was very low, about one-twentieth of the activity in our spinal cord myelin preparation.

There have been reports $\mathrm{s}^{8,34}$ of proteinase and $\beta$-naphtylaminidase activity in peripheral nerve myelin. In our peripheral myelin preparation we could not show any significant proteinase activity and no $\beta$-naphthylaminidase activity. The membrane fraction banding at $\mathrm{I} 7.6 \%$ sucrose $(\mathrm{w} / \mathrm{w})$ seems to be identical to the "myelin-like" fraction reported by Agrawal et al..$^{25}$ and Morgan et al..$^{35}$ and are shown here also to have high $2^{\prime}, 3^{\prime}$-cyclic nucleotide- $3^{\prime}$-phosphohydrolase activity, high activity of $5^{\prime}$ nucleotidase, absence of the basic protein and a phospholipid to protein ration of 0.9 The disc electrophoresis patterns reveal the pronounced differences between the peripheral and central nervous system myelin preparation; differences in lipid ${ }^{6}$ and protein composition ${ }^{36}$ have already been reported.

As has been shown, the method described in this paper is applicable for the preparation of myelin membranes from central and peripheral nerves with high purities and high recoveries, and can be used for purification of myelin membranes from individual nerves or small specific parts of the brain.

\section{ACKNOWLEDGEMENTS}

I would like to thank Dr. E. Victoria, N. I. H., Bethesda, for his valuable advice in the primary stage of the work, Dr. G. L. Scherphof and Dr. A. Verkley for the electron microscopy, and Miss F. Vossenberg for her excellent technical help.

I am grateful to Professor L. L. M. van Deenen for his encouragement and suggestions during the course of this study. 


\section{REFERENCES}

I L. A. Autilio, W. T. Norton and R. D. Terry, J. Neurochem., I I (1964) r 7.

2 E. F. Soto, L. S. De Bohner and M. del Carmen-Calvino, J. Neurochem., 13 (1966) 989.

3 B. Gerstl, L. F. Eng, R. B. Hayman, M. G. Tavaststjerna and P. R. Bond, J. Neurochem., 4 (1967) 66I .

4 M. G. Rumsby, P. J. Riekkinen and A. V. Arstila, Brain Res., 24 (1970) 495.

5 G. Rouser and S. Fleischer, Lipids, 4 (I969) 239.

6 J. S. O'Brien, E. L. Sampson and M. B. Stern, J. Neurochem., I4 (1967) 357.

7 N. Miani, C. Cavalotti and A. Caniglia, J. Neurochem., I6 (1969) 249.

8 C. W. Adams, Y. H. Abdulla, D. R. Turner and O. B. Bayliss, Nature, 220 (1968) I7r.

9 P. J. Riekkinen and J. Clausen, Brain Res. I5 (1969) $4 \mathrm{I} 3$.

Io D. E. Green, E. Murer, O. H. Hultin, S. H. Richardson, B. Salmon, G. P. Brierley and H. Baum, Arch. Biochem. Biophys., II 2 (1965) 635.

ir H. D. Tisdale, in R. W. Estabrook and M. E. Pallman, Methods in Enzymology, Vol. ro, Academic Press, New York, 1967, p. 213.

I2 H. Weissbach, T. E. Smith, J. W. Daly, B. Witkop and S. Udenfriend, J. Biol. Chem., 235 (I960) $\mathrm{I}$ i6o.

I3 G. L. Sottocasa, B. Kuylenstierna, L. Ernster and A. Bergstrand, J. Cell Biol., 32 (1967) 4 I5.

I4 M. G. Burdon, R. M. S. Smellie and J. N. Davidson, Biochim. Biophys. Acta, 9I (1964) 46.

I5 R. Wattiaux and C. de Duve, Biochem. J., 63 (I956) 606.

I6 P. Emmelot and C. J. Bos, Biochim. Biophys. Acta, I 20 (I966) 369.

I7 S. M. Duttera, W. L. Byrne and M. C. Ganoza, J. Biol. Chem., 243 (1968) 22 I6.

I8 J. A. Goldburg and A. M. Rotenburg, Cancer, i (1958) 283.

I9 H. O. Michel, J. Lab. Clin. Med., 34 (1949) I 564.

20 R. W. Olafson, G. I. Drummond and J. F. Lee, Can. J. Biochem., 47 (1969) 96I.

2 I O. H. Lowry, N. J. Rosebrough, A. L. Farr and R. J. Randall, J. Biol. Chem., I93 (195I) 265.

22 C. J. F. Böttcher, C. M. van Gent and C. Pries, Amal. Chem. Acta, 24 (I96I) 203.

23 E. J. Victoria, L. M. G. van Golde, K. Y. Hostetler, G. L. Scherphof and L. L. M. van Deenen, Biochim. Biophys. Acta, 239 (197I) 443.

24 K. Takayama, Arch. Biochem. Biophys., I I 4 (I966) 223.

25 H. C. Agrawal, N. L. Banik, A. H. Bone, A. N. Davison, R. F. Mitchell and M. Spohn, Biochem. $J$., I 20 (1970) 635

26 D. D. Murdock, E. Katona and M. A. Moscarello, Can. J. Biochem., 47 (I969) 818.

27 R. Shapiro, F. Binkley, R. F. Kibler and I. J. Wundram, Proc. Soc. Exp. Biol. Med., I 33 (1970) 238 .

28 E. D. Day, P. N. McMillan, D. D. Mickey and S. H. Appel, Anal. Biochem., 39 (197r) 29.

29 T. Kurihara and Y. Tsukada, $J$. Neurochem., I4 (1967) I 167.

3o T. Kurihara, J. L. Nussbaum and P. Mandel, Life Sci., Io (1971) 421 .

31 N. L. Banik and A. N. Davison, Biochem. J., II 5 (1969) I05I.

32 J. L. Nussbaum, N. Neskovic and P. Mandel, J. Neurochem., I6 (r969) 927.

33 F. B. Jungalwala and R. M. C. Dawson, Biochem. J., I23 (197I) 683.

34 C. W. M. Adams, Neurohistochemistry, Elsevier, Amsterdam, I965, p. 332.

35 I. G. Morgan, L. S. Wolfe, P. Mandel and G. Gombos, Biochim. Biophys. Acta, 24I (197I) 737.

36 Y. London, Biochim. Biophys. Acta, 249 (I97I) I 88.

Biochim. Biophys. Acta, $282(\mathrm{r} 972) \mathrm{r}^{9}-204$ 